\title{
RECAUDACIÓN Y POLÍTICAS TRIBUTARIAS EN CHARCAS, FINES DEL SIGLO XVIII
}

\author{
POR \\ DANIEL J. SANTAMARÍA \\ Centro de Estudios Indígenas y Coloniales \\ Facultad de Humanidades, Universida Nacional de Jujuy \\ y Consejo Nacional de Investigaciones Científicas y Técnicas
}

\begin{abstract}
Se analizan las políticas de recaudación tributaria y las estrategias estatales de asignación de tierras a la población campesina en todo el territorio de Charcas (Bolivia) durante el periodo 1780-1810; se incluye un anexo sobre las categorías tributarias en que se dividía la población aborigen.
\end{abstract}

En un libro ya clásico de Nicolás Sánchez-Albornoz ${ }^{1}$, el lector puede encontrar, en su capítulo tres, toda la información relativa a la cuestión tributaria en Charcas (la actual Bolivia) en el siglo XVII y, en el capítulo dos, cómo esta cuestión prosigue en el XIX. La única sección del libro dedicada a las últimas décadas del XVIII es la admirable descripción de la problemática tributaria en el pequeño distrito cochabambino de Tapacarí, en el capítulo cuatro. Por ello hemos creído conveniente analizar en todo el espacio charqueño y un poco más en profundidad, el tema de la recaudación del tributo pagado por las masas indígenas y de las políticas tributarias elaboradas y aplicadas por los oficiales de la Real Hacienda, muy vinculadas a las políticas de concesión de tierras a las comunidades aborígenes, durante el crucial período que transcurre de la Revolución Tupamarista (17801783) a las Guerras de Independencia (1812-1825). Esta revisión se nutre en las Revisitas de Indios de ese período; sobre las caracterís-

1 Nicolás SÁNCHEZ-AlbORNOZ, Indios y Tributos en el Alto Perú, Lima, Instituto de Estudios Peruanos, 1978. 
ticas de estos recuentos, sus dificultades prácticas y su utilidad heurística, remito a un artículo anterior ${ }^{2}$. También se nutre con lo discutido con (y aprendido del) propio Sánchez-Albornoz sobre las cifras de tributarios y sus clases, en conversaciones privadas y en algún que otro congreso.

Por derecho de conquista todas las tierras americanas se convierten en realengas; a sus ocupantes aborígenes, la Corona les exige el pago de un tributo anual. Este tributo se constituye mediante la suma de una tasa fija por individuo varón, entre 18 y 50 años, y una tasa variable de acuerdo al potencial ecológico de las tierras ocupadas. Los miembros plenos de las antiguas comunidades de campesinos autóctonos son denominados «originarios» y son quienes pagan mayores tasas; la masa de mestizos e indios que o disponen eventualmente de tierras (o nunca las tienen) se conocen como «forasteros». El término «agregado» se reserva habitualmente a aquellos originarios que habiendo migrado a las ciudades o a haciendas de españoles, abandonando muchos años sus tierras de origen, deciden regresar en algún momento, convirtiéndose en virtuales arrendatarios de los «originarios».

En Charcas, las tasaciones varían enormemente por el variapinto potencial ecológico de las tierras concedidas: extensos desiertos salinos al oeste del altiplano, donde la riqueza se mide por el número de camélidos; punas secas y valles altos, donde se siembra maíz en estrechos espacios verdes y regados; valles más bajos, finalmente, con clima subtropical, donde se cultivan coca y una serie de vegetales alimenticios y medicinales, de gran aceptación en todos los mercados urbanos. La precisión de este potencial es una preocupación básica de las autoridades coloniales después de la Real Ordenanza de Intendentes de 1782. Las Revisitas (que por ello constituyen una rica fuente documental) revelan el número de indios tributarios y procuran llevar un detallado presupuesto de ingresos, de modo que las autoridades puedan saber qué recaudarán del enorme territorio de Charcas. El problema reside en que, para cobrar tributos, las comunidades y los «forasteros» deben tener tierras asignadas. Y aquí la necesidad fiscal choca con la evolución del mercado de tierras, con el aprovechamiento progresivo de los valles y con toda una serie de pautas culturales de uso del suelo y de las comunicaciones que impi-

2 Daniel Santamaría, «La propiedad de la tierra y la condición social del indio en el Alto Perú. 1780-1810». Desarrollo Económico, 66, Buenos Aires, IDES, 1977.

R. I., 1997, n. $^{\circ} 209$ 
den que la relación reparto de tierras y capacidad tributaria alcance una ecuación perfecta. En la primera parte de esta nota examinamos los mecanismos habituales de recaudación tributaria y en la segunda, las políticas tributarias emprendidas por las autoridades en su intento por superar esas contradicciones. En el Anexo definimos las designaciones comúnmente empleadas entonces para cada «categoría tributaria».

\section{LA RECAUDACIÓN TRIBUTARIA}

Si la política borbónica procura aumentar y regularizar la recaudación tributaria es porque tanto por los mecanismos tradicionales de recaudación empleados hasta entonces como por la discutible precisión de los datos de las Revisitas, la recolección de tasas ha enfrentado variadas perturbaciones. Para evitarlas, los funcionarios de Charcas proponen tres soluciones: aumentar las tasas, igualar las de originarios y forasteros $\sin$ tierras $^{3}$ y exigir un pago no anual sino semestral (futuros «tercios» de San Juan y Navidad). Algunos revisitadores argumentan en contra de esos proyectos: en primer lugar, los comuneros se rehusarían o simplemente no siempre podrían cumplir su prestación; tampoco podría embargárseles sus posesiones porque, en referencia a los agregados a tierras del común, «los más las arriendan». Además, al enterar la tasa de manera escalonada, los comuneros reciben del curaca-gobernador uno o dos reales como contraprestación (tinka) gastándola, según estos funcionarios, en coca y chicha ${ }^{4}$. Sumada a los rezagos habituales, esta costumbre suele dejar en descubierto a los curacas, cualquiera sea el número de contribuyentes a su cargo. En realidad, se trata de una iliquidez monetaria provocada a cambio de la expectativa de incrementar la renta/trabajo

3 En el Anexo se ofrece una descripción detallada de todas las categorías tributarias mencionadas en el texto.

4 «La challa o tinca es un trago de aguardiente o un poco de chicha que se da al indio a tiempo que entera el tercio de su tributo como por uso de obsequio; no es pensión del cacique sino del cobrador que se nombra, quien es el que hace los viajes, el que costea estos obsequios y el que le entera la plata al cacique para que éste, después de deducir el tanto por ciento que le corresponde ponga el dinero en manos del señor subdelegado.» Matías TERRAZAS, Informe a Manuel Josef de Uclés sobre los colquerunas y los gravámenes de los caciques, 18 de septiembre de 1797 (Archivo General de la Nación Argentina [en adelante AGN] Justicia, 36: 1048. 
comunal. Aumentar o igualar el tributo, por consiguiente, no hace más que agravar estas circunstancias negativas ${ }^{5}$.

Entre otras dificultades, una de las más significativas es la corrupción de curacas y cobradores que interfiere en los arreglos de los patrones de tributarios, ya que cuando consideran hábiles para tributar a los «pxóximos» (los varones de 14 a 18 años), les cobran sumas arbitrarias, en algunos casos excesivas y otras veces, según el caso, menores a la tasa establecida. Cuando el apoderado fiscal que acompaña a los revisitadores debe arreglar la recaudación en los términos prescritos por la Instrucción Metódica (sancionada el primero de julio de 1784), las tasas esperadas apenas coinciden con las que los comuneros están dispuestos a pagar, originándose permanentes fricciones $^{6}$.

Además, el deterioro de las economías comunales amenaza la recaudación aun de las tasas «menores» y mucho más de las «mayores», según la época del año. Los contribuyentes de las últimas, cuando se ven indigentes, pagan sólo la tasa menor a su curaca, quien aunque admite de mala gana esa rebaja unilateral, prefiere aceptarla asumiendo su responsabilidad ante la Real Hacienda antes de exponerse a la fuga del comunero y a la pérdida de la tasa total ${ }^{7}$. Cuando la recaudación comienza a hacerse por tercios o semestres se advierten inconvenientes sobre todo en el pago del segundo tercio, cuando ya no existen, como durante el primero, las abundantes reservas de granos posteriores a la cosecha ${ }^{8}$. Por las mismas razones fracasan todos los intentos por imponer un tributo cuatrimestral en reemplazo del semestral ${ }^{9}$.

\footnotetext{
5 Juan A. SEGovia y Francisco LóPEZ, Sobre la revisita del partido de Porco, 1792 (AGN-Hacienda, 69).

6 Expendiente sobre la rebaja de tributos que solicitan los indios de Poopó en René ARCE AGUIRRE, «El cacicazgo en las postrimerías coloniales», Avances, ${ }^{\circ}{ }^{\circ}$, La Paz, 1978, p. 48.

7 Juan A. SEGovia y Francisco LÓPEZ, Informe sobre la provincia de Porco, 1792 (AGN-Guerra y Marina, 18: 21).

8 «Regularmente se dificulta el cobro del tercio de Navidad porque como la subsistencia de estos naturales depende de la agricultura a que están dedicados sin tener más comercio ni industria, ni arbitrio, sólo en el tercio de San Juan en que tienen a mano los productos de sus cosechas se puede allanar la recaudación y esto en años que no sean estériles o calamitosos.» Sobre la Revista del Partido de Tapacarí, 1787 (AGN-XIII-18-2-1).

9 Revisita de Pilaya y Paspaya, 1787 (AGN-XIII-18-5-5).
} 
Las autoridades coloniales dejan en manos de los curacas hasta el cuatro por ciento del entero y no el uno por ciento establecido por las ordenanzas, por las dificultades en cumplir la «gruesa» total y por las frecuentes ausencias de sus tributarios, especialmente en los valles donde es más fácil huir u ocultarse. Esta situación lleva a muchos de curacas a declararse judicialmente en quiebra y renunciar a sus cargos $^{10}$. Esta inseguridad en el cobro de las tasas los persuade a sacar de muchos pueblos más tasa de la asignada, exigiéndoselas hasta a las viudas y a los «reservados» (los mayores de 50 años o por inválidos), a los padres por sus hijos ausentes o viceversa y aun por personas fallecidas. El revisitador de Chayanta denuncia el «pernicioso abuso de mantener vivos en los padres los nombres de muchos muertos y ausentes y exigir la contribución de los hijos, viudas o parientes que quedaban con las tierras vacantes de su asignación» ${ }^{11}$. Los revisitadores de Porco comprueban que varias viudas y reservados pagan tributos indebidos al curaca para que les permita el usufructo de su tierra, por lo demás ampliamente protegido por la legislación ${ }^{12}$.

Ante esta incertumbre generalizada, la política tributaria oficial intenta presionar a los propios recaudadores: el Capítulo XXVI de la Instrucción Metódica restringe a los «reservados» la función del curacazgo exigiendo tributo a sus hijos primogénitos, a quienes no les corresponde legalmente la exención que gozan por costumbre. Los gobernadores, curacas, principales, alcaldes y segundas son, desde 1792 , censados como «reservados» y no como curacas ${ }^{13}$. Iguales problemas enfrenta la cobranza del tributo entre los yanaconas. El Conde de Canillas, Visitador de las Reales Cajas de Potosí, sanciona en 1705 su recaudación por el sistema de arrendamientos o remate entre particulares. En febrero de 1773 el virrey de Lima, aceptando una propuesta del Fiscal de la Real Hacienda (marzo de 1766), extingue lo arrendamientos y encarga la recaudación a los corregidores, lo que origina de inmediato grandes abusos. Uno de los modos más efectivos de acumular fue, precisamente, la usurpación de tributos, mecanismo al que también apelan, como se sabe, curacas y cobrado-

\footnotetext{
10 [6] f. $5 \mathrm{v}$.

11 Sobre la revisita de Chayanta, 1793 (AGN-XIII-19-1-2).

12 [6] fs. $5 \mathrm{v}-6$.

13 [6] f. $1 \mathrm{v}$.
} 
res. En el cuadro 1 tenemos un ejemplo de usurpación denunciado en 1780 en el partido de Porco ${ }^{14}$.

\section{CUADRO 1}

MONTOS USURPADOS DE LA GRUESA DE TRIBUTOS POR LOS CORREGIDORES DE PORCO EN 1780 (EN PESOS)

\begin{tabular}{lrrr}
\hline \multicolumn{1}{c}{ DOCTRINA } & GRUESA & USURPACIÓN & $\%$ \\
\hline Porco & 172 & 121 & 70 \\
Puna & 3.608 & 2.754 & 76 \\
Tomabe & 3.147 & 2.296 & 73 \\
Cayza & 2.176 & 1.010 & 46 \\
Toropalca & 1.562 & 836 & 53 \\
Chaqui & 3.082 & 2.096 & 68 \\
Miculpaya & 825 & 418 & 51 \\
Bartolo & 703 & 471 & 67 \\
Coroma & 1.143 & 950 & 83 \\
Yura & 1.326 & 736 & 55 \\
Tacobamba & 1.504 & 864 & 57 \\
Potobamba & 787 & 476 & 60 \\
Siporo & 402 & 245 & 61 \\
Esquiri & 653 & 429 & 66 \\
Mataca & 434 & 265 & 61 \\
Tinguipaya & 3.440 & 2.340 & 68 \\
TOTAL & $\mathbf{4 4 . 9 6 4}$ & $\mathbf{1 6 . 3 0 7}$ & 65 \\
\hline
\end{tabular}

Cuando la Corona declara abolidos los corregimientos (1782), la recaudación queda a cargo de los subdelegados. La Instrucción Metódica ha establecido que los hacendados recauden los tributos prima facie y que luego los entreguen a los corregidores (luego de 1783 a los subdelegados). El gobernador de Potosí propone continuar con el anterior sistema de arrendamientos a despecho de la Instrucción, porque la gran movilidad de los yanaconas imposibilita en la práctica el cobro regular ${ }^{15}$. En efecto, el carácter migrante y propenso a la fuga de yanaconas y de forasteros sin tierras, resta sentido a la prác-

\footnotetext{
14 AGN-Criminales, 17: 20 (1780).

15 Miguel SÁENZ, Informe a la Contaduría General de Retasas, 20 de noviembre de 1802 (AGN-Hacienda, 69: 1842).
}

R. I., 1997, n. $^{\circ} 209$ 
tica de adjudicarle a los hacendados la responsabilidad del entero. Explicando su argumento, Francisco de Paula Sanz, Intendente de Potosí, le señala al virrey Arredondo que «consistiendo principalmente en indios vagos de ningún domicilio, sin tierras que cultivar y los más sin ocupación conocida, es tan contingente su cobranza como imposible reducirla a las reglas generales de la masa común de tributos» ${ }^{16}$.

Seis años después, Sanz insiste en su argumento casi en los mismos términos, esta vez ante el virrey Avilés ${ }^{17}$. Aun para los mismos subdelegados hay dificultades: Oráa y Gainza denuncia en 1799, refiriéndose a los yanaconas reales, que «no teniendo éstos estabilidad, residencia fija ni bienes raíces, contra quienes recurrir (como garantía) son infinitos los desfalcos que se sufren al tiempo de hacer efectiva la recaudación ya por sus fugas a las provincias colindantes, ya por sus traslaciones a la Villa de Potosí y aun a los minerales de este partido donde es muy difícil y a veces imposible exigirles sus tasas» ${ }^{18}$. Francisco de Zufriategui demuestra en 1804 la ineficiencia de los arrendamientos a cargo de los subdelegados y la imposibilidad de completar los enteros. Tomando en cuenta los yaconas empadronados entre el 27 de octubre de 1791 y el 20 de noviembre de 1792 , enumera 1176 tributarios con tasa de siete pesos, 65 de cinco pesos y 15 de tres. Con esas cifras, la recaudación debe haber suministrado 8.602 pesos al año; sin embargo, desde 1783 el subdelegado aporta 4.700, una pérdida anual de 3.902. Por supuesto no queda claro si se trata de una maniobra dolosa de los subdelegados para conservar el sobrante o si realmente esa fuerza de trabajo migrante paga menos del total previsto ${ }^{19}$.

La recaudación aumenta en los últimos años del siglo: por ejemplo, la retasa de Porco prevé para 1770 un monto total de 35.232 pesos. Quince años después, la obligación de entero del subdelegado

\footnotetext{
16 Sanz a Arredondo, 26 de septiembre de 1793 (AGN-IX-33-8-3).

17 «Los yanaconas del rey son vagos de ningún domicilio, sin tierras que cultivar y sin ocupación conocida y es tan contingente su cobranza como imposible reducirlos a las reglas generales... cuando por otra parte su misma insubsistencia y la libertad con que viven de mudar de domicilio cuando les acomoda hacen impracticable el medio prevenido por la Instrucción de Revisitas de poner estos indios a cargo de los hacendados que se obligan a satisfacer a Su Majestad el respectivo tributo de ellos», Sanz a Avilés, 26 de julio de 1799 (AGN-XIII-18-10-3).

18 N. ORAA Y GAINZA, Revisita del partido de Porco, 1799 (AGN-XIII-19-2-1) fs. 2-2v.

19 AGN-Hacienda, 69: 1842.
} 
se fija en 49.000, lo que supone un aumento del 39 por ciento, equivalente al 2,6 anual ${ }^{20}$. En los cuadros que siguen se reproducen las cifras brutas de ingreso en concepto de tributo y su evolución sobre el índice-promedio producido entre 1778 y 1804 en las cuatro intendencias de Charcas.

\section{CUADRO 2A}

INTENDENCIA DE LA PAZ

RECAUDACIÓN DE TRIBUTOS Y EVOLUCIÓN INDICIAL (1778-1804) ÍNDICE PROMEDIO: $100=222.982$ PESOS

\begin{tabular}{|c|c|c|}
\hline AÑO & CIFRA BRUTA & EVOLUCIÓN \\
\hline 1778 & 134.796 & 60,4 \\
\hline 1779 & 179.324 & 80,4 \\
\hline 1780 & 198.115 & 88,8 \\
\hline 1781 & 2.746 & 1,2 \\
\hline 1782 & 0 & 0,0 \\
\hline 1783 & 0 & 0,0 \\
\hline 1784 & 165.663 & 74,3 \\
\hline 1785 & 228.437 & 102,4 \\
\hline 1786 & 248.520 & 111,4 \\
\hline 1787 & 227.950 & 102,2 \\
\hline 1788 & 243.701 & 109,3 \\
\hline 1789 & 236.241 & 105,9 \\
\hline 1790 & 215.486 & 96,6 \\
\hline 1791 & sin datos & sin datos \\
\hline 1792 & 184.027 & 82,5 \\
\hline 1793 & 252.381 & 113,2 \\
\hline 1794 & 208.328 & 93,4 \\
\hline 1795 & 284.804 & 127,7 \\
\hline 1796 & 285.460 & 128,0 \\
\hline 1797 & sin datos & sin datos \\
\hline 1798 & 290.928 & 130,5 \\
\hline 1799 & 282.173 & 126,5 \\
\hline 1800 & 320.755 & 143,8 \\
\hline 1801 & sin datos & sin datos \\
\hline 1802 & 279.424 & 125,3 \\
\hline 1803 & 376.097 & 168,7 \\
\hline 1804 & 283.237 & 127,0 \\
\hline
\end{tabular}

20 Contaduría Principal de Potosí, 4 de mayo de 1785 (AGN-XIII-18-10-2).

R. I., 1997, n. $^{\circ} 209$ 


\section{CUADRO 2B}

INTENDENCIA DE POTOSÍ

RECAUDACIÓN DE TRIBUTOS Y EVOLUCIÓN INDICIAL (1778-1804) ÍNDICE PROMEDIO: $100=149.992,2$ PESOS

\begin{tabular}{lrr}
\hline AÑO & CIFRA BRUTA & EVOLUCIÓN \\
\hline 1778 & 75.809 & 50,5 \\
1779 & 125.119 & 83,4 \\
1780 & 88.851 & 59,2 \\
1781 & 123.032 & 82,0 \\
1782 & 159.366 & 106,2 \\
1783 & 128.681 & 85,8 \\
1784 & 159.733 & 106,5 \\
1785 & 133.055 & 88,7 \\
1786 & 86.924 & 57,9 \\
1787 & 157.122 & 104,7 \\
1788 & 156.702 & 104,5 \\
1789 & 161.129 & 107,4 \\
1790 & 154.890 & 103,3 \\
1791 & 159.569 & \\
1792 & 165.706 & 110,5 \\
1793 & 161.028 & 107,3 \\
1794 & 170.049 & 113,4 \\
1795 & 175.179 & 116,8 \\
1796 & 171.145 & 114,1 \\
1797 & 173.244 & 115,5 \\
1798 & 160.016 & 106,7 \\
1799 & 160.142 & 106,8 \\
1800 & 152.240 & 101,5 \\
1801 & 185.645 & 123,8 \\
1802 & 172.396 & 114,9 \\
1803 & 137.879 & 91,9 \\
1804 & 195.141 & 130,1 \\
\hline
\end{tabular}

R.I., 1997, n. ${ }^{\circ} 209$ 


\section{CuAdro 2C}

INTENDENCIA DE CHARCAS

RECAUDACIÓN DE TRIBUTOS Y EVOLUCIÓN INDICIAL (1779-1803) ÍNDICE PROMEDIO: $100=49.125,9$ PESOS

\begin{tabular}{lcc}
\hline AÑO & CIFRA BRUTA & EVOLUCIÓN \\
\hline 1779 & 34.763 & 70,8 \\
1780 & 31.641 & 64,4 \\
1781 & sin datos & sin datos \\
1782 & 44.791 & 91,2 \\
1783 & 37.028 & 75,4 \\
1784 & 40.316 & 82,1 \\
1785 & sin datos & sin datos \\
1786 & sin datos & sin datos \\
1787 & sin datos & sin datos \\
1788 & 53.884 & 109,7 \\
1789 & 55.065 & 112,1 \\
1790 & 43.399 & 88,3 \\
1791 & 57.592 & 117,2 \\
1792 & 49.123 & 100,0 \\
1793 & 52.414 & 106,7 \\
1794 & 47.000 & 95,7 \\
1795 & 59.221 & 120,5 \\
1796 & 53.477 & 108,8 \\
1797 & 52.853 & 107,6 \\
1798 & 52.999 & 107,9 \\
1799 & 53.248 & 108,4 \\
1800 & 53.100 & 108,1 \\
1801 & 52.968 & 107,8 \\
1802 & 53.309 & 108,5 \\
1803 & 53.464 & 108,8 \\
\hline
\end{tabular}

R. I., 1997, n. 209 
CuADro 2D

INTENDENCIA DE COCHABAMBA

RECAUDACIÓN DE TRIBUTOS Y EVOLUCIÓN INDICIAL (1779-1804)

ÍNDICE PROMEDIO: $100=73.988,5$ PESOS

\begin{tabular}{lcc}
\hline AÑO & CIFRA BRUTA & EVOLUCIÓN \\
\hline 1779 & 39.714 & 53,7 \\
1780 & 21.850 & 29,5 \\
1781 & 44.283 & 59,8 \\
1782 & 40.162 & 54,3 \\
1783 & 46.351 & 62,6 \\
1784 & 56.216 & 76,0 \\
1785 & sin datos & sin datos \\
1786 & 30.545 & 41,3 \\
1787 & 87.388 & 118,1 \\
1788 & 87.708 & 118,5 \\
1789 & 82.880 & 112,0 \\
1790 & 85.748 & 115,9 \\
$1791-95$ & sin datos & sin datos \\
1796 & 91.209 & 123,3 \\
1797 & 91.307 & 123,4 \\
1798 & 96.078 & 129,8 \\
1799 & 96.313 & 130,2 \\
1800 & 95.523 & 129,1 \\
1801 & 95.130 & 128,6 \\
1802 & 96.167 & 130,0 \\
1803 & 96.488 & 130,4 \\
1804 & 98.710 & 133,4 \\
\hline
\end{tabular}

La recaudación tributaria constituye la mitad de los ingresos fiscales en Cochabamba y casi el 60 por ciento en La Paz. No llega al 20 por ciento en la de Charcas ni al 10 por ciento en Potosí, en este caso por la alta incidencia de lo recaudado del resto de las cajas fiscales establecidas en distritos mineros y que aportan a Potosí (el rubro Otras Tesorerías). Por último, la gruesa del tributo se reparte entre el sínodo correspondiente a los curas de cada doctrina, la comisión del curaca o cacique-gobernador y la porción real que suele 
oscilar en un 70 por ciento de la gruesa. Observemos un ejemplo de distribución: Chayanta entre 1772 y $1777^{21}$.

\section{CUADRO 3}

DISTRIBUCIÓN DE LA GRUESA DE TRIBUTO EN CHAYANTA (1772-1777)

\begin{tabular}{lccccccc}
\hline AÑO & GRUESA & SÍNODO & $\%$ & CURACA & $\%$ & CORONA & $\%$ \\
\hline $1772-73$ & 69.534 & 22.294 & 32 & 1.930 & 3 & 45.309 & 65 \\
$1774-75$ & 68.629 & 22.176 & 32 & 1.287 & 2 & 45.167 & 66 \\
1776 & 78.644 & 22.294 & 28 & 1.271 & 2 & 55.078 & 70 \\
1777 & 52.008 & 14.863 & 29 & 739 & 1 & 36.406 & 70 \\
\hline
\end{tabular}

En el cuadro 4 se observa el modo en que la tributación participa en la recaudación fiscal de cada Intendencia en 1778-1804.

\section{CUAdro 4}

PARTICIPACIÓN PORCENTUAL DE RUBROS IMPOSITIVOS EN LAS CUATRO INTENDENCIAS DEL ALTO PERÚ (1778-1804)

\begin{tabular}{lcrrrrr}
\hline INTENDENCIA & $(\mathrm{A})$ & $(\mathrm{B})$ & $(\mathrm{C})$ & $(\mathrm{D})$ & $(\mathrm{E})$ & $(\mathrm{F})$ \\
\hline Cochabamba & 1 & 50 & 20 & 21 & & 8 \\
La Paz & 5 & 57 & 20 & 12 & & 6 \\
Charcas & & 20 & 19 & 43 & & 18 \\
Potosí & 28 & 9 & 5 & 5 & 51 & 2 \\
\hline
\end{tabular}

(A) Ingresos provenientes de la actividad minera.

(B) Ingresos provenientes de la recaudación tributaria.

${ }^{21}$ Nicolás De Urzaingui, Cuentas del corregidor de Chayanta, Potosí. Chayanta. Expedientes (1774-1779) (AGN-XIII-23-3-1). En 1767 la distribución del tributo ingresado en Chayanta sobre un total de 46.356 pesos se hizo de la siguiente manera: por sínodo anual a los catorce curas doctrineros del partido 14.863 pesos (32 por ciento), comisión anual a los curacas 1.286 pesos ( 3 por ciento), al corregidor 1.562 pesos ( 3 por ciento), por salarios a los justicias 557 pesos (1 por ciento), por doctrinas forasteras 948 pesos ( 2 por ciento), sobrante para el Rey 27.137 pesos (59 por ciento). Cf. Margesí de los repartimientos de la provincia de Chayanta, Potosí, 1767 (AGN, Chayanta. Expedientes 1774-1779, XIII-23-3-1).

R. I., 1997, n. $^{\circ} 209$ 
(C) Ingresos provenientes de impuestos fijados sobre la actividad comercial y la circulación de mercancías.

(D) Ingresos provenientes de las concesiones de cargos administrativos, militares y ecleasiásticos.

(E) Ingresos provenientes de las recaudaciones de las otras tesorerías dependientes.

(F) Otros ingresos no determinados previamente o esporádicos.

A fines del siglo XVI, el virrey Toledo había fijado el tributo personal (una verdadera capitatio) en cinco pesos anuales. Los campesinos que disfrutaban de tierras realengas, fueran originarios o agregados, debían pagar además una tasa proporcional al valor estimado oficialmente por ellas: «cuanta es la porción de tierras que usufructan, tanta es la cuota tributaria» 22 . De este modo, el volumen de las tasas pagadas por los campesinos variaba según su categoría tributaria y dentro de cada una de ellas según el potencial ecológico de las tierras adjudicadas. Si la producción agrícola no superaba el nivel de subsistencia, la tasa se imponía sobre la posesión de rebaños. Toledo había establecido para los originarios de las Yungas (los valles lluviosos del pedemonte) cuatro cestos de coca al año y para los mitmakquna o mitimaes dos, pero a principios del XVIII, como el sarampión dispera a los campesinos reduciendo el ingreso fiscal, los visitadores aumentan la carga a siete y tres cestos respectivamente. La razón de la menor tasa de los mitimaes obedece a que no tienen tantos cocales como los originarios.

A los forasteros con el nombre de yanaconas del Rey o yanaconas de estancias, se les cobraría cinco pesos en plata por no tener acceso a los cocales y mantenerse en fincas del valle, de propiedad de españoles, ceñidas a una pobre producción de maíz y legumbres $^{23}$. Hacia 1777, Felipe de Haedo dice que a los originarios se les cobra una tasa oscilante entre nueve y once pesos. En el altiplano, en unos casos más que en otros, la esterilidad de las tierras comunales es tan manifiesta que la tasa baja al nivel de la del forastero, como por ejemplo, en algunos puntos de Larecaja en $1792^{24}$. En el resto del partido, en cambio, el revisitador aumenta la tasa en especies a

\footnotetext{
22 Revisita del Partido de Omasuyos, tomo III, 1786 (AGN-XIII-17-5-4).

23 Francisco ORTIZ DE LA MAZA, Representación del Defensor de los Caciques Principales del Pueblo de Camata, 1707 (AGN-Padrones de La Paz, XIII-17-2-41).

24 Ayllos Chinchaysuyu, Yani, Guaycho, Collana, Guarina, Viacha, Pucarani y Hachacache con un total de 72 originarios (Revisita de Larecaja, 1792, AGN-XIII-17-7-3).
} 
siete pesos para los originarios que tienen «tierras de panllevar» y a seis para los forasteros que habitan tierras estériles ${ }^{25}$.

José María Aliaga, cura de Timusi, señala que con «suavísimas palabras y eficaces persuasiones» los funcionarios convencieron a los tributarios, y que éstos quedaron agradecidos, porque «a cada individuo» le dieron «tierras de aquéllas que llamaban encomiendas», es decir, tierras vacas (abandonadas) de españoles. El principal efecto de esta medida es, para el mismo Aliaga, un mayor arraigo para los residentes y un estímulo para el regreso de los ausentes. El cura de Hilabaya pone el acento en que el arraigo también prende entre muchos yanaconas que sin derecho a tierras del común «estaban expuestos a vaquear (esto es, quedar vacantes o sin trabajo), volviéndose inútiles». El cura de Italaque advierte que se entregaron más tierras a los forasteros convertidos formalmente, entonces, en originarios, exigiéndoseles dos pesos más de $\operatorname{tasa}^{26}$. Aunque todas las disminuciones se registraran como «tasas menores», no por ello pierde el comunero su categoría original; con el tiempo, las variaciones llegan a ser muy precisas según el grado de conocimiento del potencial ecológico de los terrenos concedidos por las autoridades (algo que los campesinos prefieren mantener oculto) o la categoría en cuestión ${ }^{27}$. Por su parte, el capitán de yanaconas acostumbra cobrar a la vez hasta tres años de tributo según el tiempo de residencia de los «mingados» o según el lapso que ellos mismos han indicado estar fuera de las ciudades. También se relaciona con esto que unos fueran yanaconas del Rey, pagando mayor tributo, y otros criollos, por ejemplo en Potosí, que pagan menos «por cuya distinción tienen

\footnotetext{
25 Agustín Ruiz De SANTA María, Informe del cura y vicario del Pueblo de Curba sobre el aumento de tributos en Larecaja, 1792 (AGN-Justicia, 28: 845).

26 Testimonio de las actuaciones que han dicho todos los curas de este partido de Larecaja de orden del señor Gobernador, Provisor y Vicario General y a pedimento del Subdelegado don José Sánchez Barreda (AGN-Justicia, leg. 28, exp. 845, IX-31-6-1).

27 En 1786 los originarios con tierras de Pacajes pagan 75 reales, los del repartimiento de Guaqui 78, en Santiago Machaca 72 y los de Tiahuanaco 80. En el resto del partido la tasa es de 77 reales. Nueva Matrícula del partido de Pacajes, 1786 (AGN-XIII-17-6-4). También en Pacajes, como en muchos otros lugares del altiplano, es frecuente el originario de tasa menor a cinco pesos. Los forasteros de los valles templados, aun aquéllos que no poseen tierras, suelen tributar más que los del altiplano: pagan 56 reales los de Pilaya en 1787, y los de Porco, en 1799, y 60 reales los de Tomina 98. Las categorías tributarias especiales pagan tasas igualmente especiales: los churumatas de Tarija pagan 69 reales, los uros 24 en Carangas y 48 en Omasuyos; los kachas pagan 40 y los yanaconas 24.
} 
a satisfacer diferente tasa por igual tiempo los indios que parecen de una misma condición» ${ }^{28}$.

Una de las cuestiones fundamentales no es tanto el monto, como la composición de la tasa. Borah señala que a mediados del XVI el servicio personal es prohibido en la Nueva Galicia como forma del tributo y que también se termina con el transporte del tributo en especie ${ }^{29}$. A ello sigue la reducción a uno o dos artículos y finalmente el pago en moneda, una respuesta a la voluntad de los propios campesinos sabedores del precio creciente a que se venden sus productos en el mercado colonial. Si bien es posible creer que fuera así en todas las zonas rurales con fácil acceso a mercados urbanos, es difícil reconocerlo en aquellas áreas donde el acceso es más limitado y los vínculos comerciales responden más a la reciprocidad ${ }^{30}$ que a la acumulación monetaria. Sin embargo, el tema merece un tratamiento especial en Charcas, donde en apariencia, el tributo pagado íntegramente en plata no solamente nunca reemplaza del todo al tributo en especie sino que este reemplazo no es generalmente aconsejado por los funcionarios reales.

En 1664 los yungas pagaban su tributo en coca y en servicios de conducción a Sorata y a la Puna, lo que motivó entonces una queja al virrey Santisteban ${ }^{31}$. En 1792 los revisitadores de Larecaja uniforman el tributo y reúnen las tasas en especie «que antes contribuían los naturales en aves y frutos de sus cosechas, quedando reducidas en plata efectiva, arreglándolos a que paguen los indios originarios siete pesos al año, los agregados y forasteros que disfrutan tierras seis y los yanaconas cinco» ${ }^{32}$.

28 Pedro Vicente CAÑETE, Reflexiones sobre las actuaciones obradas en la Intendencia de Potosí relativas a la conducta de los curas de Chayanta y auto en su razón proveído con remisión a los subdelegados de los partidos para que se publique en forma de bando, 1795 (AGN-Biblioteca Nacional, 296: 4678).

29 BORAH, Woodrow Borah (1970), «Los tributos y su recaudación en la Audiencia de Nueva Galicia durante el siglo XVI», en Bernardo García Martínez (Ed.), Historia y Sociedad en el Mundo de Habla Española. Homenaje a José Miranda, El Colegio de México, México.

30 El concepto de «reciprocidad» se emplea aquí en el sentido restringido de intercambio de bienes sobre una medida subjetiva de valor y sin referencia a medidas objetivas como el dinero. De todos modos parece anodino querer explicitar estas diferencias sobre base documental.

31 Jean Vellard, «Contribución al estudio de las poblaciones indígenas de las Yungas de La Paz (Bolivia)», Runa, 12, Buenos Aires, 1969-1970, pp. 331-332.

32 [27]. 
Los funcionarios de Puno ignoran aún en 1792 si los subdelegados cobran el tributo en moneda o en especie; se refieren a que anteriores provisiones regulaban las tasas parte en plata, parte en bestias de carga, chuño, ropa, etcétera. Sospechan que los contribuyentes pagan quizás «como en otras provincias» todo el tributo en dinero ${ }^{33}$. Los campesinos de Carabaya tienen la costumbre de pagar en coca «la misma que siempre siguen con la diferencia de entregarla a su cacique por estar derogada la admisión de esta especie y aunque ésta padece de varias alteraciones en su precio, al tributo se le abona seis pesos constantemente por cuyo motivo la cuota del originario mayor ha estado a cinco pesos y un real y la del forastero a dos pesos y tres reales» ${ }^{34}$.

La diferencia radica en la oscilación provocada en el monto real de la recaudación por las variaciones de precio de mercado de los bienes contribuidos. Una evolución negativa de precios disminuye el valor del tributo así como un alza los eleva. Los campesinos pueden conocer con precisión este movimiento y por consiguiente, la variación relativa del valor de sus contribuciones. En un período de relativo estancamiento de precios, como son los últimos años del XVIII, tratan de saldar su tasa en plata y sin duda no vacilarían pagar una tasa mayor si ello llevara implícito el goce de más y mejores tierras y por ende, mayores expectativas de lograr una producción mayor, cuyo valor de mercado superara el tributo.

El informe de la Contaduría General de Retasas de $1798^{35}$ toca de lleno este problema: si el campesino opta por pagar su tasa en metálico (algo permitido por las Reales Cédulas), debe cobrársele al precio que tengan en la provincia respectiva la o las especies sobre las que se establece el tributo, ya sea en parte o íntegramente. De ese modo, el tributario en cuestión no sólo pagará la tasa designada, sino el aumento del valor de la especie, para compensarle al arrendador la mayor utilidad que le produciría recibiéndola al precio de la tasa y

\footnotetext{
33 AGN-Tribunal de Cuentas. Intendencia de Puno (1778-1800), IX-12-4-10.

34 Informe sobre la Revisita del partido de Carabaya, 1786 (AGN-Tribunal de Cuentas, Intendencia de Puno, 1778-1800, IX-12-4-10). Los campesinos de Tapacarí pagan mitad en plata, mitad en maíz, cf. [9]. En Atacama «todos o la mayor parte de los tributarios pagan su respectiva asignación en frutos de labranza o en otras especies de industria», cf. Sobre la Revisita del Partido de Atacama, 1787 (AGN-XIII-18-10-4).

35 Informe de la Contaduría General de Retasas, 20 de noviembre de 1798 (AGNTribunal de Cuentas, Intendencia de Puno, 1778-1800, IX-12-4-10).
} 
comercializándola por su cuenta. El funcionario añade que si hay igualdad entre el precio de las especies en las retasas y el precio a que éstas se venden en los mercados provinciales, puede concederse que los campesinos paguen en metálico según la tasa, pero habiendo diferencia, se recomienda no se les permita ese pago sino en la especie señalada «para no inferir perjuicio al interesado».

\section{LAS POLÍTICAS TRIBUTARIAS}

La directa correlación entre tenencia de tierras y capacidad tributaria brinda la posibilidad de medir el valor de la tierra agrícola por el cómputo de las tasas pagadas por encima de la capacitación individual. Una recopilación de tasas por localidad a través del prisma de las categorías tributarias permitiría elaborar un mapa para señalar con cierta precisión el potencial ecológico entonces evaluado de las cuatro intendencias de Charcas. En su momento, las evaluaciones dependen de factores coyunturales: el retraso técnico de la agricultura grava la economía campesina: «es por la pobreza de la tierra que los caciques y exactores tropiezan hoy con grandes dificultades para realizar sus enteros aún respecto a los originarios que poseen tierras» ${ }^{36}$. La carencia de tierras realengas - tema clave de la cuestión tributaria- marca el límite de las concesiones comunales e indirectamente, el de la recaudación físcal. No es extraño que sean muchos los funcionarios inquietos por aumentar los respartos y asegurar una recaudación más suculenta.

En 1572 las clases de contribuyentes habían quedado reducidas a dos: los que componían las comunidades o «pueblos de indios» y los yanaconas. Entonces no había, en realidad, más que campesinos reducidos, porque los yanaconas eran pocos. Rápidamente, la inmigración y el traslado masivo de poblaciones creó aquel tercer estrato que durante la colonia se llamó forastero y que por no habérsele concedido tierras realengas no pagaba tributo (o lo pagaba en corta cantidad) ni concurría a los trabajos comunes. Estas franquicias multiplicaron su número al punto de que «los pueblos de indios» se ven progresivamente sobrecargados de forasteros incapaces de pagar tasa. El hábito de designar como tales a todos los campesinos migrantes

36 [12]. 
de las comunidades que habiéndose ausentado de ellas volvían luego de unos años, reduce, entre otras cosas, el servicio de mita a Potosíi7.

La numeración general de los forasteros ordenada por el duque de la Palata comienza en 1683 y concluye en 1689: entonces se establece esos forasteros paguen como originarios y que marchen a la mita. Como la medida es resistida, el sucesor de La Palata, conde de la Monclova, debe eximirlos del servicio personal, ordenando que sus tasas se igualen a la que antes pagaban los yanaconas reales, siempre y cuando no excediera de siete pesos y en caso de ser menor, se atuvieran a la «tasación o costumbre». En toda Charcas, los forasteros están desde entonces sometidos a una tasa de cinco pesos (excepción hecha de Potosí donde pagan siete) y de este modo siguen multiplicándose mientras disminuyen los originarios. Finalmente, en el curso del XVIII, terminan mezclándose, distinguiéndose «los de origen» (que gozan de acceso directo a las tierras del común) y los forasteros que no lo tienen, pese a residir en los pueblos. Sin embargo, los agregados a las comunidades tienen, como hemos visto, cierto acceso a la tierra, a veces tan amplio como para igualar la tasa $^{38}$.

En 1707, Francisco Ortiz de la Maza advierte que hay en Yungas tierras abandonadas por los originarios y otras baldías que podrían entregarse a forasteros para que, explotándolas, puedan pagar una tasa similar. Pero como estos migrantes «están sumamente pobres que ni aun cama en qué dormir tienen», y como para efectuar la roza y la limpieza del monte necesitan fondos suficientes, parece muy difícil llevar esto a buen término. Además, la mayoría procede de la Puna y tiene dificultades en adaptarse al clima caluroso de las Yungas ${ }^{39}$.

Más avanzado el siglo, se hace corriente ofrecer en el mercado las muchas tierras vacantes que incorpora la colonización de tierras nuevas y la crisis poblacional del siglo anterior. También se venden las poseídas por comunidades con superficies excedentes a las asignadas a cada tributario. También se intenta solucionar los litigios entre tierras comunales según los requerimientos de cada una: cual-

37 Enrique TANDETER, Coacción y Mercado. La Minería de La Plata en el Potosí Colonial, 1692-1826, Buenos Aires, 1992, II.

38 Informe sobre la Visita de Azángaro, 1788 (AGN-Tribunal de Cuentas, Intendencia de Puno, 1778-1800, IX-12-4-10).

39 [24].

R. I., 1997, n. ${ }^{\circ} 209$ 
quier comunidad puede perder sus tierras si otra demuestra su necesidad real. Incluso las autoridades practican redistribuciones periódicas $^{40}$ dentro de las comunidades mismas. En 1786 el revisitador de Omasuyos reconoce que es imposible brindarles a los forasteros y a los uros la misma cantidad de tierras que a los originarios ${ }^{41}$.

A fines del XVIII la cuestión se generaliza: concluida la etapa de formación de las haciendas coloniales y recuperada la curva demográfica del campesinado, el problema de la distribución de tierras realengas y de su adecuación a las tasas se hace cada vez más espinoso. La solución unilateral de aumentar de categoría a los forasteros sin repartirles tierras entraña «poner en combustión los peligrosos pueblos del recinto, contribuir a la despoblación y frustrar los interesantes fines de las Revisitas» ${ }^{42}$. La misma exigencia fiscal sobre los originarios es proporcional a las concesiones que cultivan pues «a más de ser estériles se las han disipado considerablemente los circunvecinos, de modo que necesitan que los bienes de comunidad les ayuden o sufraguen para satisfacer su tercio ${ }^{43}$.

Estos bienes comunales pueden representar, en efecto, una garantía del entero si no fueran, como se ha visto, víctimas de un despojo sistemático por parte de los funcionarios. Tampoco esa solución puede admitirse entonces. En Porco, la misma escasez de tierras hace que muchos originarios sin acceso al cultivo y por ello impotentes para pagar los diez pesos de tasa «hayan salido a la clase de forasteros sin tierras con el objeto de pagar sólo siete pesos al año» ${ }^{44}$. Los originarios se multiplican en desmedro del común acceso a la economía comunal; el fisco no puede proporcionarles a todos ellos los terrenos necesarios para el pago de la tasa. En algunos pueblos, como corolario de este fenómeno, el aumento del tributo no es proporcional al de la masa de tributarios, lo que entraña un verdadero riesgo para las finanzas reales. Como no hay gobernadores fijos, se debe dividir la cobranza entre personas de prestigio en cada comunidad,

40 Karen Spalding, De Indio a Campesino. Cambios en la Estructura Social del Perú Colonial, Lima, IEP, 1974, p. 120.

${ }^{41}$ [23].

42 [12].

43 Revisita del Partido de Yamparaes, 1786 (AGN-XIII-18-5-4).

44 Sobre la Revisita del Partido de Porco, 1799 (AGN-XIII-19-2-1). 
quedando cada uno de ellos, en virtud de las ordenanzas de Revisita vigentes, exentos del pago ${ }^{45}$.

Ante el temor de un aumento, los originarios de Larecaja piden la adjudicación de los terrenos ocupados por los curacas y la agregación de las tierras realengas arrendadas ${ }^{46}$. El mismo cura del pueblo de Sorata advierte más tarde que, sin ninguna resistencia, los originarios se han obligado a contribuir la tasa superior por habérseles distribuido las tierras y chacras como tasa en especie, proporcional a su riqueza ${ }^{47}$. En la misma región hay comunidades que sobreviven en páramos tan pobres que sólo saldan cinco pesos al año ${ }^{48}$.

En los años posteriores a la Revolución Tupamarista, el número de forasteros, en muchos lugares considerablemente mayor que el de originarios, genera una intensa presión social sobre los hacendados y las mismas comunidades, celosas de sus privilegios y prerrogativas. El curaca de Sorata explica que «la igualación del número de indios originarios con los agregados y forasteros es imposible por la falta de tierras y que éstos son cuadruplicadamente el número de aquéllos, respecto de que no gozan tierras algunas de comunidad y se mantienen a fuerza de su industria viviendo bajo los auspicios de originarios y españoles hacendados (como arrenderos o jornaleros) viajando a los minerales en calidad de fleteros o conductores y son tan pobres que apenas tienen cama en qué dormir» ${ }^{49}$. La única solución es ampliar los repartos y acomodar a muchos forasteros para que hasta el propio fisco se beneficie percibiendo más tasas originarias, pero las tierras del Rey no alcanzan y más aún, disminuyen sin cesar por las continuas composiciones de los terratenientes. A raíz de este grave problema, se piensa convertir a todo el campesinado en forastero, reivindicar las concesiones y repartirlas o aun arrendarlas para paliar la caída de la recaudación derivada de la primera medida. El proyecto apunta a «cortar sus congresos y comunidades por ser principios inductivos de la inquietud»; pero la medida es demasiado impolítica. Los funcionarios del partido de Sicasica son los primeros en juzgar «gravísimas las dificultades que se nos ofrecen para promover es-

\footnotetext{
45 [19] fs. 1v-2.

46 [25].

47 Narciso HERNANI BONIFAZ, Informe del Cura y Vicario de Sorata sobre el aumento de tributos en Larecaja, s/d (AGN-Justicia, 28: 845, IX-31-6-1).

48 [25].

49 [25].
}

R. I., $1997, \mathrm{n}^{\circ} 209$ 
pecie alguna en el particular por el inevitable trastorno de la quietud pública ${ }^{50}$.

La falta de tierra comunal y el explosivo abarrotamiento de agregados son males que éstos prefieren antes de irse como yanaconas a las fincas de españoles. El revisitador de Azángaro sospecha que con el tiempo se extinguirán todos, o casi todos, los tributarios de alta tasa y que las tierras ni siquiera servirán para graduarlas porque sólo las gozarán los forasteros, subdividiéndolas en pequeñas fracciones. La concesión de tierras especiales para los forasteros - añade - los fijará en un lugar permitiendo el cobro de su tasa y la imposición de la mita, aliviando así a los originarios, que la detestan ${ }^{51}$.

Mal o bien, los agregados aprovechan tierras realengas dentro de la comunidad, compartiendo sus pautas culturales y sociales. Los funcionarios de la revisita de Larecaja reaccionan contra esta práctica pretextando que se trata de introducir más indios tributarios en tierras de repartimiento sino de reglar el tributo de los que ya están en ellas ${ }^{52}$. La opción es aumentar el tributo sin un aumento paralelo de tierras o proceder a la inversa, repartiendo más tierras para aumentar el tributo. La falta de terrenos, sobre todo en los valles, inhibe la segunda opción pero la primera puede acarrear, sin ninguna duda, graves consecuencias políticas. Otro revisitador propone reducir el número de agregados al de originarios, repartir a los primeros la mitad de los terrenos entregados a los últimos y cobrarles la correspondiente mitad del tributo. Otro de la misma revisita cree útil distribuir por las haciendas a los agregados que gozando de tierras realengas en el ayllo pagan cinco pesos de tasa como los yanaconas. Los hacendados recibirían alborozados esa masiva fuerza de trabajo y muchas parcelas quedarían disponibles para los próximos y para los agregados que se avinieran a tributar como originarios ${ }^{53}$.

Lo cierto es que nadie puede, durante el régimen colonial, desenredar esta madeja de dificultades; el problema constituye, por cierto, una pesada herencia para las autoridades republicanas y una grave amenaza para las comunidades indígenas.

50 Autos de Revisita de Tributarios formado en el Partido de Sicasica, 1786 (AGNXIII-17-7-1).

51 Informe sobre la Revisita de Azángaro, 1788 (AGN-Tribunal de Cuentas. Intendencia de Puno, 1778-1800, IX-12-4-10).

52 [25].

53 [25]. 


\title{
ANEXO \\ LAS CATEGORÍAS TRIBUTARIAS EN EL ALTO PERÚ A FINES DEL SIGLO XVIII Y PRINCIPIOS DEL XIX ${ }^{54}$
}

\section{LOS ORIGINARIOS}

Se denominaba con este nombre a todos los miembros de una comunidad aborigen, reconocida como preexistente al establecimiento español en América, reconociéndosele por ley derechos originarios sobre la tierra que ocupaban y cultivaban, y una unidad cultural basada en la lengua, la religión tradicional (unidad que se intenta conservar en su adoctrinamiento cristiano y en las jurisdicciones eclesiásticas) y en prácticas protocolares particulares. Los originarios fueron los únicos que legalmente podían actuar como mitayos en las minas y quienes estaban sometidos a un tributo mayor. Sus autoridades principales eran los caciques-gobernadores o curacas, asistidos por sus «segundas». La evolución de la economía comunal y de las categorías tributarias determinó las siguientes variedades:

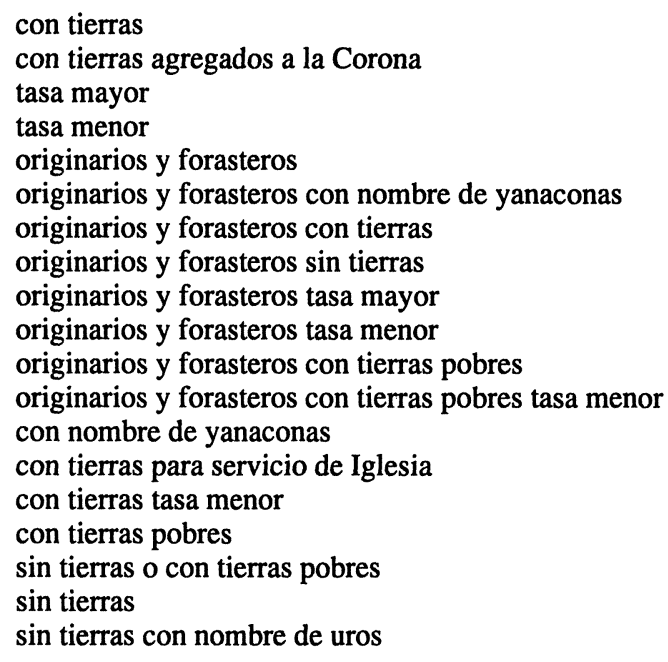

\section{LOS TINDARUNAS}

Se trata de originarios sin tierras que con este nombre aparecen en la Revisita de Tarija de 1785 trabajando en San Bernardo y en Cabeza de Toro. El revisitador señala que son

54 Una descripción de las categorías básicas en Daniel SANTAMARía [3].

\author{
R. I., $1997, \mathrm{n}^{\circ} 209$
}


llamados así «porque su destino en los principios fue el servicio de los oficiales de esta frontera, con la calidad de que por ellos pagasen su tributo; hoy, como son pocos los que han quedado de aquel fuste, no los ocupan a excepción de uno y otro vecino y los demás, como viven vagos sin tierras ni otro arraigo, se han ido disipando y han quedado en el corto número que componen las parcialidades de esta villa y Valle de la Concepción»55.

\title{
3. LOS FORASTEROS
}

En Sudamérica comienza a llamarse con este nombre, desde el siglo XVII, a una masa indefinida de aborígenes sin vinculación aparente con comunidades establecidas; se supone que constituyen el producto del mestizaje entre indio y español, por un lado, o el producto de la desorganización social y laboral de muchas comunidades indígenas originarias. Este fenómeno puede haberse producido por migración, despojo de tierras, cambios de actitudes socioeconómicas que producen radicación del aborigen en las ciudades o en el campo como productor independiente, etcétera. En general, pagan menos tributo que los originarios y no están legalmente obligados al servicio de mita. En los registros aparecen las siguientes variedades:

\author{
Forasteros \\ arrenderos de haciendas \\ con tierras \\ sin tierras \\ agregados \\ agregados con tierras \\ agregados sin tierras \\ sin tierras arrenderos de haciendas \\ legítimos con tierras \\ ilegítimos con tierras \\ ilegítimos \\ con nombre de originarios \\ con tierras con nombre de originarios \\ sin tierras con calidad de originarios \\ sin tierras de todos oficios \\ sin tierras colonos de los originarios o arrendadores \\ forasteros y yanaconas sin tierras \\ sin tierras que sirven en calidad de mitayos ${ }^{56}$ \\ con nombre de yanaconas \\ con algunas tierras
}

\section{AgREGADOS}

Muchos aborígenes que por uno u otro motivo deciden abandonar sus comunidades y que luego deciden regresar lo hacen como «agregados». Los jefes comunales les otorgan tierras bajo forma de arrendamiento; no gozan de los privilegios ni sufren las obligaciones

55 Revisita de Tarija, 1785 (AGN-XIII-18-10-4).

56 A éstos se los encuentra en el distrito de Yamparaes en 1786 y trabajan como mitayos en la Real Audiencia de Charcas, en la ciudad de La Plata. 
de los originarios si bien participan de la unidad social y religiosa de la comunidad. Aparecen estas designaciones:

\author{
Agregados \\ con tierras \\ con pocas tierras o sin tierras \\ sin tierras 57 \\ agregados y forasteros sin tierras
}

\title{
5. VECINOS
}

La caracterización de «vecinos» puede referirse tanto a aborígenes como a mestizos; en cualquier caso parecen haber sido asimilados a los rasgos esenciales de los originarios. No está comprobado documentalmente que estuvieran obligados al servicio de mita. Además de la designación mencionada aparece también la de «vecinos del pueblo con tierras».

\section{YANACONAS}

La historia del yanaconazgo tiene todavía muchas lagunas: se cree que fueron en su origen un grupo o una clase social afiliada al poder del Inca en el Tawantinsuyu. Bakewell los define como «no pertenecientes a ningún ayllu» y con status hereditario ${ }^{58}$. Su rol como jefes de los ejércitos de la Conquista o como mayordomos de las haciendas de españoles es igualmente borroso. Las Ordenanzas del Perú del virrey Francisco de Toledo los instalan como trabajadores rurales adscritos, con sus familias, en las haciendas coloniales y desde entonces y hasta comienzos del siglo XVIII no pagan tributo ni sirven a la mita minera. En las Revisitas aparecen los siguientes tipos:
Yanaconas
con tierras
sin tierras
del Rey
forasteros sin tierras
mulatos

\section{ChOlOs}

Es el nombre habitual en el mundo andino para designar a los mestizos de indio y europeo que conservan la cultura y las costumbres tradicionales de la población aborigen:

Cholos

con tierras

57 «Que por muy pobres y muchos de ellos mendigos sin formal radicación y expuestos a mudarse como regularmente lo hacen no teniendo de qué subsistir, contingentes en la plaga de tributos» (Caso en Sacaca, Chayanta, 1792).

58 Peter BaKewell, Mineros de la Montaña Roja. El trabajo de los indios en Potosí, 1545-1650, Madrid, Alianza 1989, p. 205.

R. I., $1997, \mathrm{n}^{\circ} 209$ 
agregados con tierras

sin tierras

forasteros

forasteros sin tierras

\title{
8. UROS
}

Nombre de un grupo étnico peculiar, que habita las áreas lacustres del altiplano, desde el lago Titicaca hasta el Poopó, incluyendo la cuenca del río Desaguadero que los une ${ }^{59}$.

\author{
Uros \\ con tierras \\ sin tierras \\ agregados \\ agregados con tierras \\ uruítos \\ lope Uros (Pacajes) \\ uros puenteros 60
}

\section{Churumatas}

Designación de varios grupos étnicos de origen chaqueño, que aparecen desde las estribaciones centromeridionales de la Intendencia de Charcas hasta los valles orientales del pedemonte en la actual provincia de Jujuy (Argentina). Parecen haber sido empujados hacia el sur por las invasiones chiriguanas del XVIII. Sobre ellos existe actualmente una creciente bibliografía.

\section{ZAMBAIGOS}

Se designa con este término a la población mestiza de africano y americano, si bien su generalidad impide mayores precisiones raciales. De todos modos, los zambaigos tienen poco status social y se los asimila a los forasteros.

Zambaigos

con tierras

sin tierras

forasteros

yanaconas

59 Hasta ahora lo más completo sobre este grupo Nathan WACHTEL, Le retour des ancêtres. Les Indiens Urus de Bolivie, XXè-XVIè siècles. Essai d'histoire régressive, París, Gallimard 1990. También del mismo autor, «Hommes d'eau: le problème uru (XVIè-XVIIè siècle)», Annales ESC, 33 (5-6), París, 1978.

60 «Uros que habitan en las orillas del río Desaguadero de la laguna de Chucuito los que desde la antigüedad están en costumbre de no tributar por tener el trabajo preciso de fabricar tres veces al año el puente de dicho río de los materiales de totora y cables de paja. En Matrícula de Pacajes, 1786 (AGN-XIII-17-6-4). 


\section{MitimaES}

Mitima (plural = mitimaes) es la lectura española del siglo XVI de la mitmaqkuna incaicos, poblaciones que eran deportadas en castigo o trasladadas con fines laborales a distintos puntos del Tawantinsuyu. Estos grupos nunca se afiliaron a las comunidades de originarios pero su patrón de residencia permanente y poco móvil terminó asimilándolos a los yanaconas más que a los forasteros.

\section{Mitimaes}

originarios

con tierras

\section{INDIOS}

La designación de «indio» implica simplemente a los pobladores aborígenes que por una cuestión u otra no eran incluidos dentro de las categorías tributarias al uso, si bien se les reconocía el usufructo de tierras realengas y se les obligaba al pago de tributos bastante variables. Entre las diferentes clases aglomeradas en este término aparecen:

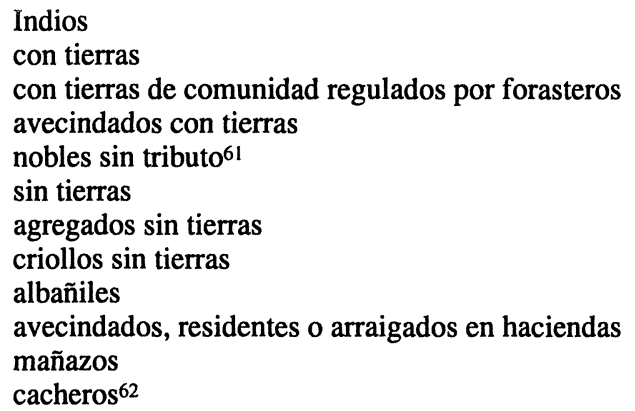

\section{OTRAS DESIGNACIONES}

Finalmente, existen denominaciones que no son estrictamente tributarias sino más bien laborales, como, por ejemplo:

- Servicio de Iglesia (indios acreditados como servidores permanentes de los curatos y doctrinas y sobre los cuales no pesaba más gravamen que su servicio personal).

- Soldados (indios enrolados en las milicias urbanas o de fronteras, sin que los documentos censales consignen el motivo de dicho enrolamiento; era habitual que

61 (Se refiere a los miembros del ayllu —o comunidad - Inga, a quienes se reconocía como descendientes legítimos de los antiguos monarcas del Cusco y estaban, en consecuencia, exentos de todo tributo u obligación laboral).

62 Se llamaba así a quienes habitaban en la orilla de los desplayes del río Desaguadero, llamada Yruyto.

\section{R. I., $1997, \mathrm{n}^{\circ} 209$}


quienes cometiesen delitos fueran condenados a servir en la milicia; es posible que muchos aborígenes actuaran simplemente como mercenarios).

- Kachas (se trata de una masa, tan indefinida como la de los forasteros, que levantaban los desechos minerales en las entradas de los socavones durante el receso de sábado y domingo. Aunque esa actividad era ilegal, se los toleraba porque se pensaba que la limpieza efectuada permitía reiniciar las tareas normales la mañana del lunes sin perder tiempo) ${ }^{63}$.

- Arrenderos (constituyen un grupo social aparentemente pequeño formado por aborígenes forasteros, mestizos y hasta posiblemente españoles pobres. Es posible que el término sea una simple abreviatura de «forasteros arrenderos»).

- Criollos y originarios con tierras (se llamaba así a productores rurales independientes asimilados jurídicamente a los originarios; el término «criollo» sugiere un mestizo de europeo y aborigen con prácticas culturales europeas).

- Sirvientes (finalmente, la categoría de sirviente es muy amplia y bastante confusa; lo eran los servidores de las iglesias, el personal doméstico de las haciendas, los niños aborígenes entenados, personas de confuso origen étnico y mestizos de distinta procedencia siempre y cuando vivieran en una unidad doméstica española).

Tax gathering policies and State strategies on land assignation to peasant population are analyzed in Charcas (Bolivia) during the period 1780-1810; it is included an annex enumerating all tax categories into which indigenous population was classified.

63 Sobre los kachas, ver Eduardo MARTIRE, «Tolerancias, prevenciones y regulación participadora de los indios "capchas" de Potosí en la explotación del Cerro», Estudios sobre Política Indigenista Española en América, III, Valladolid, 1977; Enrique TANDETER, «La producción como actividad popular: "ladrones de minas" en Potosí», Nova Americana, 4, Torino, 1981; Thomas ABERCROMBIE, «Qaqchas and la plebe in "rebellion": Carnival vs. Lent in 18th century Potosí», Primer Congreso Internacional de Etnohistoria, Buenos Aires, 1989. 